\title{
Feasibility of Concentrated Photovoltaic System Based on Convex and Fresnel Lenses
}

\author{
Asmaa S. Ibrahim ${ }^{1}$, S. M. El-Ghanam ${ }^{1}$, W. Abd El-Basit ${ }^{1}$ and F. A. S.Soliman ${ }^{2}$ \\ 1- Electronic Res. Lab., Physics Dept., Faculty of Women for Arts, Science, and \\ Education, Ain-Shams Univ., Cairo, Egypt. \\ 2- Nuclear Materials Authority, P. O. Box 530-Maadi-11728, Cairo, Egypt.
}

\begin{abstract}
The present paper is mainly concerned with the performance improvement of concentrated photovoltaic systems based on convex and Fresnel lenses with different geometrical properties (diameters and focal lengths), subjected to artificial light source "Incandescent lamp" as a simulation to sunlight. A number of experiments have been executed to study their effects on all the electrical parameters of si- mono crystalline photovoltaic cell $(2.0 \mathrm{~cm} \times 1.0 \mathrm{~cm})$, as well the concentrated light intensity. The morphology of elemental composition and the spectral transmittance applying Scanning Electron Microscope and FT-IR Spectrometer of both the convex -and Fresnel -lenses were investigated, demonstrating high optical quality of the lenses. For convex lens with $9.0 \mathrm{~cm}$ in diameter, the obtained results show significant direct increasing of short circuit current, open circuit voltage, maximum output power, fill factor, and efficiency of PV cell as well the concentrated light intensity, where their values were increased from $0.32 \mathrm{~mA}, 0.28$ Volt, 0.04 $\mathrm{mW}, 0.46$ and $9.55 \%$ as well $0.226 \mathrm{klux}$ up to $6.72 \mathrm{~mA}, 0.45$ Volt, $1.85 \mathrm{~mW}, 0.6$ and $25 \%$, as well 3.5 klux, respectively. Considering the Fresnel lens with diameter of $42.43 \mathrm{~cm}$, the given parameters were increased up to $78 \mathrm{~mA}, 0.454$ Volt, $21.6 \mathrm{~mW}, 0.6$ and $30 \%$ as well $35.0 \mathrm{klux}$, respectively.
\end{abstract}

Keywords: Concentrated photovoltaic, light concentrators, convex lens, Fresnel lens, mono voltage and output crystalline photovoltaic cell, short circuit current, open circuit power.

\section{Introduction}

Today, concentrated photovoltaic systems (CPV) are used to increase the effectiveness of photovoltaic cells ( $\underline{\text { receiver}})$ using lenses or mirrors to concentrate direct light on highly efficient solar cells (N. Tien and S. Shin, 2016). Concentrated photovoltaic systems make use of low cost materials such as optical concentrators lenses/mirrors made of glass and plastic, to capture the solar energy shining on a fairly large area and focusing onto a smaller area, where the PV cell is (Y. A. Abdel-hadi, 2005). The ratio of input to output aperture areas defines the concentration ratio of the concentrating system. The significant decrease of the required photovoltaic cell area provides a pathway to lower cost, as expensive semiconductor material is replaced with inexpensive mirrors or lenses (Antonio, et al., 2007, K. Shanks, et al., 2016 and Guiqiang Li, 2013). In this concern, the main target 
of the present work is to shed further light on the performance improvement of a photovoltaic system whenever operates in CPV technique.

\section{Concentrated Photovoltaic System}

The prototype technique of CPV system built for the present study was based on a silicon mono crystalline cell with area of $2.0 \mathrm{~cm}^{2}(2.0 \mathrm{~cm} \times 1.0 \mathrm{~cm})$ and a set of convex- and Fresnel lenses of the magnifying glass with different focal lengths (f) and diameters (D), as illustrated at Table (1). The optical source, incandescent lamp, was placed at a long distance from the lens in order to ensure that the falling light beam is in parallel at the point of measurements.

Table (1): Geometric properties of Convex - and Fresnel -lenses.

\begin{tabular}{|ccc|}
\hline Lens Type & Diameter range & Focal length range \\
\hline Convex & $2.0 \mathrm{~cm}-9.0 \mathrm{~cm}$ & $5.0 \mathrm{~cm}-39.8 \mathrm{~cm}$ \\
\hline Fresnel & $5.0 \mathrm{~cm}-42.43 \mathrm{~cm}$ & $21.6 \mathrm{~cm}-30.5 \mathrm{~cm}$ \\
\hline
\end{tabular}

Convex lens is a converging one, whereas parallel light rays passing through it, the refracted rays converge at one point called the principal focus (Fig. 1a). The distance between the principal focus and the center of the lens is called the focal length. Therefore, converging parallel rays at a focal point so as to increase the concentrated light intensity is the only means to tap the diluted solar energy (P. K. Trivedi, et al., 2015 and ISO, 2008). On the other hand, a Fresnel lens is a chain of prisms, where each prism represents the slope of the lens surface (Fig. 1b). Most Fresnel lenses selected for solar energy application had been designed for the collection of solar rays which were imaging devices. The imaging Fresnel lens refracts light from an object and forms an image in the focal plane which is impacted by aberrations because of the inaccurate manufacturing of the prism tips and grooves ( $R$. Leutz and A. Suzuki, 2001 and Davis. A, 2011). Applications such as mono crystalline photovoltaic generation of electricity are often equipped with imaging Fresnel lenses and accurate tracking has to be employed to keep the focus of the lens in place on the receiver.

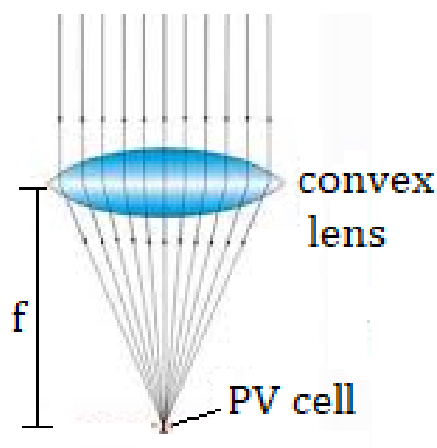

(a)

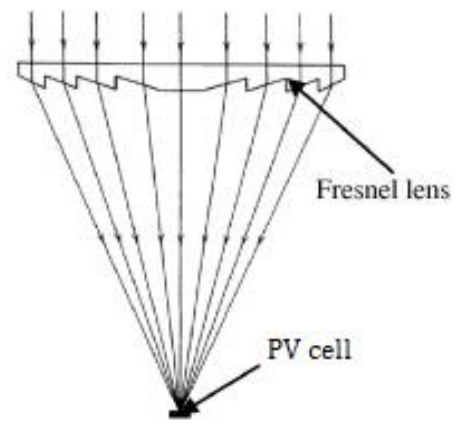

(b)

Fig. (1): Design of the concentrated photovoltaic system based on bi-convex lens (a) and Fresnel lens (b). 
The focal length of an optical system is a measure of how strongly the system converges or diverges light. The optical system converges a set of incident rays falling on its aperture from a distant object to its focus. We consider here only thin lens, hence displacement of the light ray is negligible. Thus, for thin lenses, the ray through the optical center of the lens is a straight line. If the distant object is sun, then sunrays (parallel) converge to a focus. It with a shorter focal length has greater optical power than one with a long focal length; that is, it bends the rays more sharply, bringing them to a focus in a shorter distance (S. Avireni, 2005).

\section{Results and Discussion}

\subsection{Elemental Composition of Lenses}

A Scanning electron microscope (SEM) is a type of microscopes that produces images of a sample by scanning it with a focused beam of electrons. The electrons interact with atoms in the sample, producing various signals that contain information about the sample's surface topography and composition. The electron beam is generally scanned in a raster scan pattern, and the beam's position is combined with the detected signal to produce an image. SEM can achieve resolution better than 1.0 nanometer. Specimens can be observed in high vacuum, in low vacuum, in wet conditions (in environmental SEM), and at a wide range of cryogenic or elevated temperatures (Stadtländer CT, 2007). Figure (2) shows representation of the morphology of elemental composition of two convex lenses; as an example. Also, Table (2) illustrates major, minor and traces element of the investigated convex lenses samples.

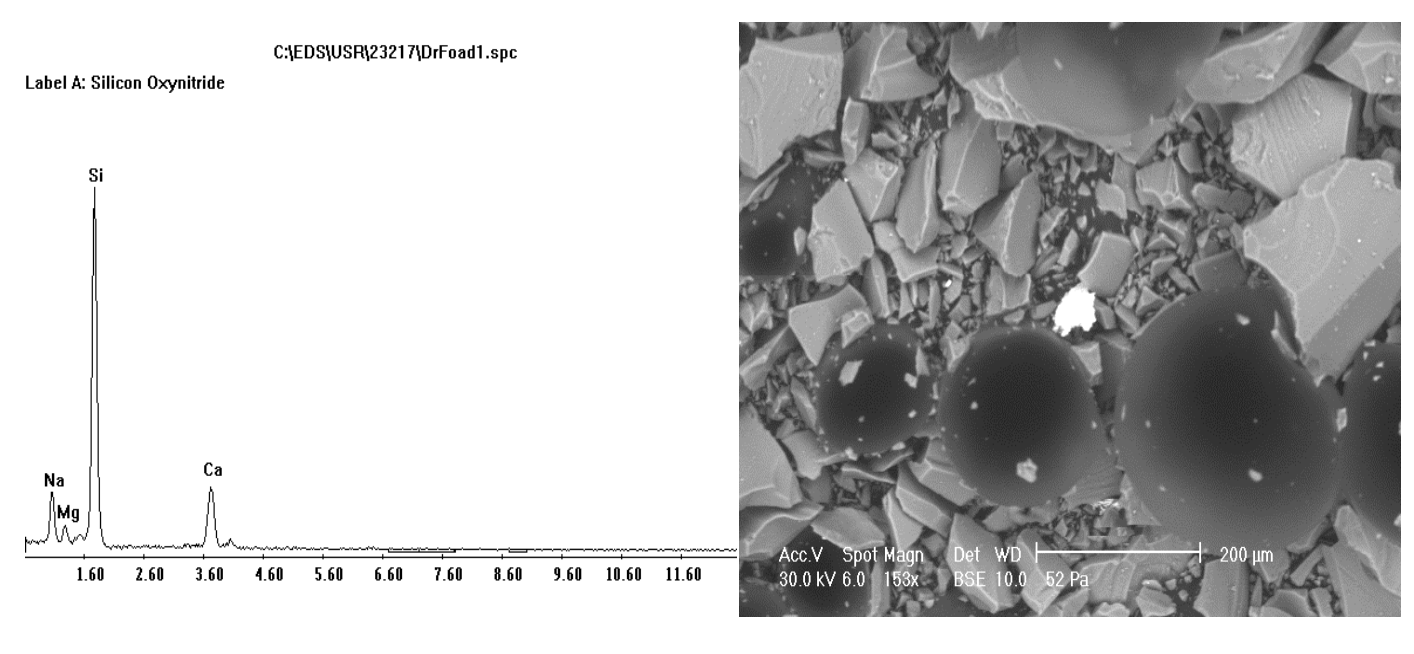

(a)

(b) 
Label A: Silicon 0xynitride

C:\{EDSUUSR|23217|DrFoad6.spc

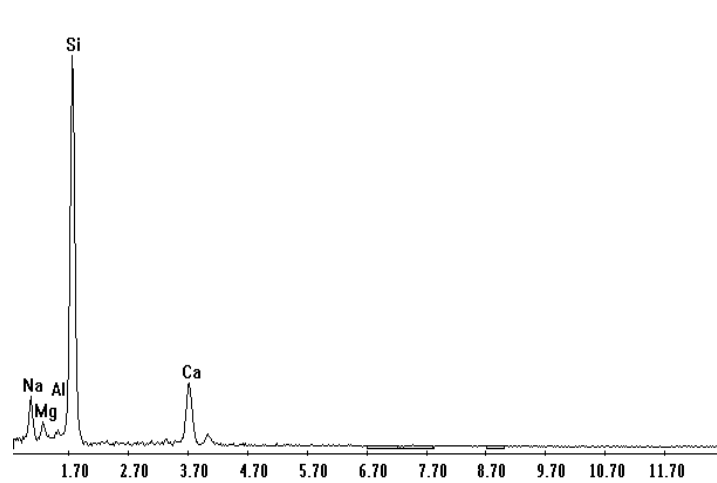

(c)

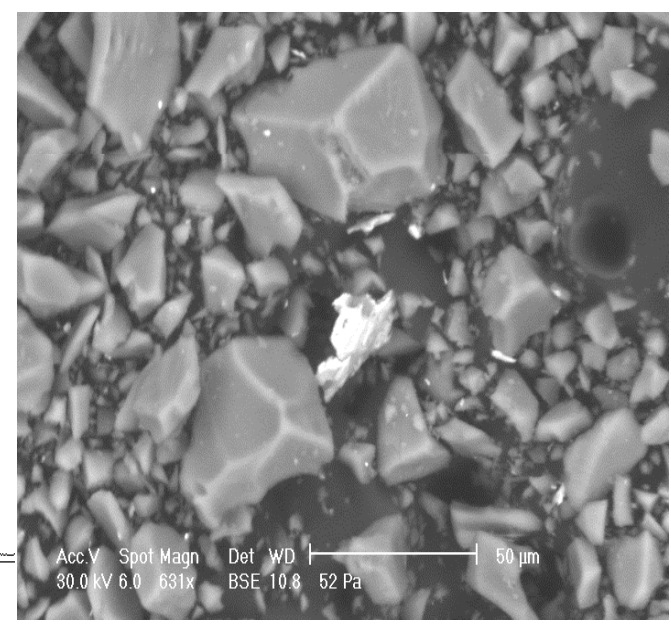

(d)

Fig. (2): Spectral data and representation of the morphology of elemental composition for two convex lenses obtained using a Scanning Electron Microscope (SEM).

Table (2): Major, minor and tracke elements of convex lenses.

\begin{tabular}{|ccccccc|}
\hline $\begin{array}{c}\text { Sample } \\
\text { No. }\end{array}$ & $\mathbf{N a}, \boldsymbol{\%}$ & $\begin{array}{c}\mathbf{M g}, \\
\mathbf{\%}\end{array}$ & $\begin{array}{c}\text { Al, } \\
\mathbf{\%}\end{array}$ & $\mathbf{S i}, \boldsymbol{\%}$ & $\mathbf{C a}, \boldsymbol{\%}$ & $\begin{array}{c}\text { Total, } \\
\mathbf{\%}\end{array}$ \\
\hline $\mathbf{1}$ & 14.54 & 5.36 & $\ldots$. & $\mathbf{6 4 . 6 3}$ & 15.46 & 100 \\
\hline $\mathbf{2}$ & 14.54 & 5.46 & $\ldots$. & $\mathbf{6 4 . 9 3}$ & 15.04 & 100 \\
\hline $\mathbf{3}$ & 12.34 & 4.24 & 3.03 & $\mathbf{6 5 . 0 2}$ & 15.37 & 100 \\
\hline $\mathbf{4}$ & 13.80 & 4.66 & 3.05 & $\mathbf{6 5 . 0 2}$ & 13.61 & 100 \\
\hline $\mathbf{5}$ & 13.31 & 5.35 & 3.07 & $\mathbf{6 3 . 9 9}$ & 14.27 & 100 \\
\hline $\mathbf{6}$ & 10.91 & 4.05 & 2.38 & $\mathbf{6 6 . 8 9}$ & 15.78 & 100 \\
\hline
\end{tabular}

\subsection{Spectral Transmittance of Lenses}

The spectral transmittance of both the convex - and Fresnel lenses (Figs. 3 and 4) were plotted using Nicolet 6700 FT-IR Spectrometer which is a Spectrophotometer for the MidInfra-Red range operating between 400 and $4000 \mathrm{~cm}^{-1}(2.5-25 \mu \mathrm{m})$ and the spectral transmitance was comprised between 65 and $100 \%$, thus demonstrating the high optical quality of the lenses. 

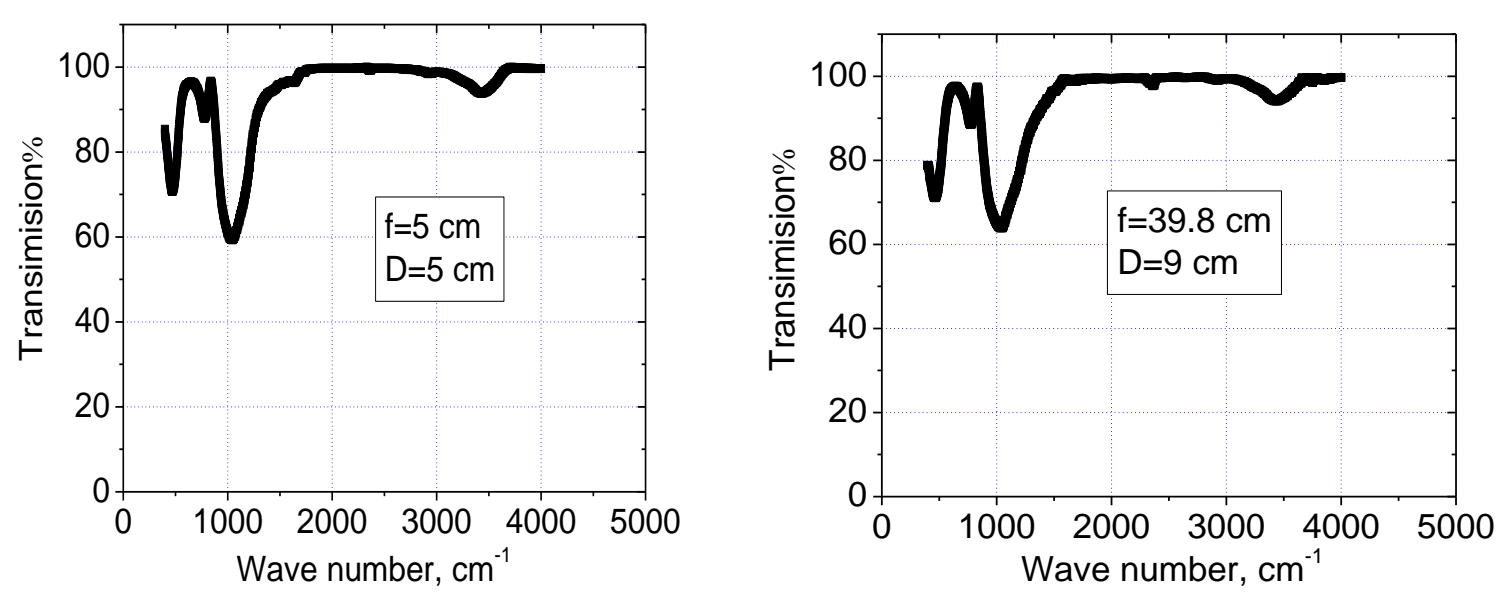

Fig (3): Spectral transmittance of two convex lenses.

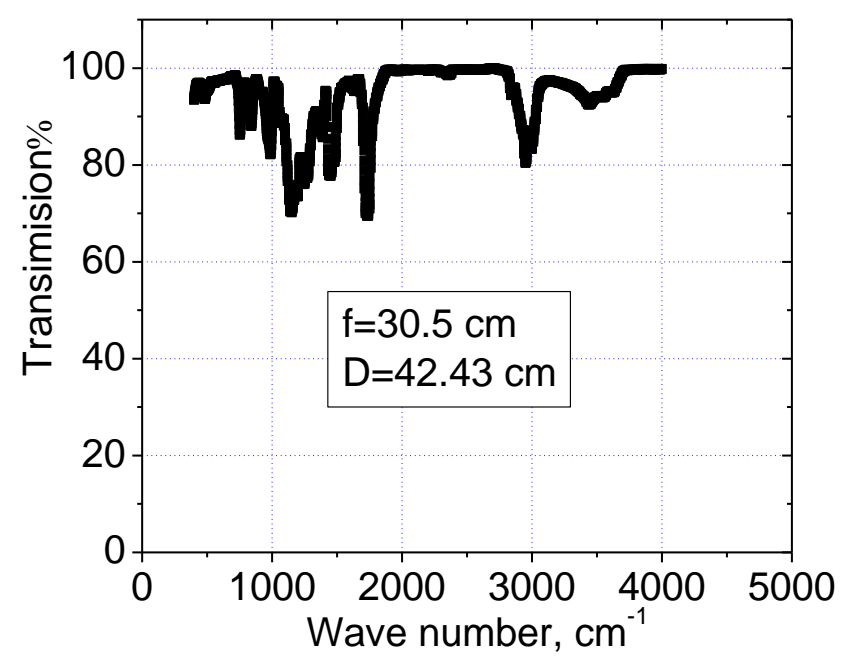

Fig (4): Spectral transmittance of Fresnel lens.

\section{ץ, r. Lenses Geometrical Properties Effect on the Electrical Characteristics of PV Cells 3.3.1. Cell- Lens Distance}

The concentrated light intensity and short circuit current of the mono crystalline silicon PV cell with area of $2.0 \mathrm{~cm}^{2}$ was measured while varying the cell-lens distance. Observations were taken in the aforesaid experiment by keeping the lens at different positions so that focusing effect of falling light on the photovoltaic cell can be varied (M. Wiesenfarth, 2014 and S. Avireni, 2005). Figure (5) shows the cell-lens distance dependences of concentrated light intensity and short circuit current of PV cell for two lenses with different focal lengths of (a) convex lens with constant diameter equal $5.0 \mathrm{~cm}$ and (b) Fresnel lens with constant diameter of $42.43 \mathrm{~cm}$. From which, it is evident that, when the cell-lens distance approaches near to the focal length, the concentrated light intensity on the cell and short circuit current increase and will be maxima at the focus. 

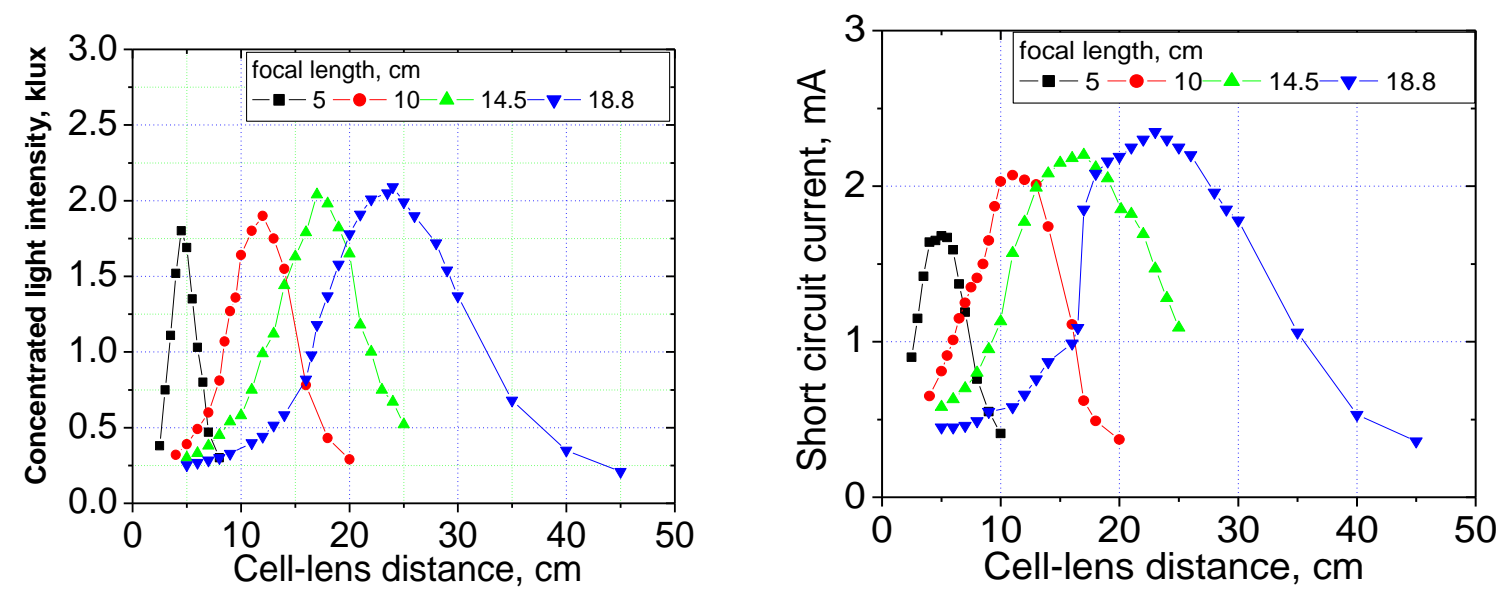

(a)
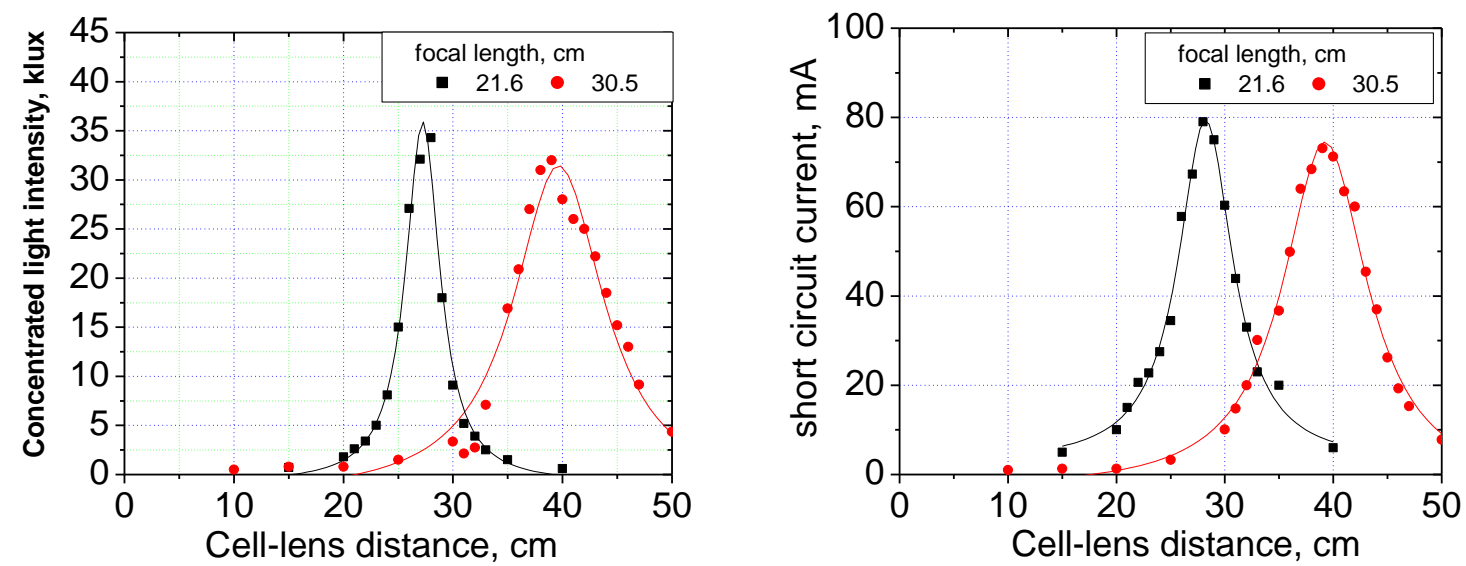

(b)

Fig. (5): Cell - lens distance dependences of concentrated light intensity and short circuit current of PV cell, plotted for two lenses with different focal lengths and at constant diameter of Convex lens (a) and Fresnel lens (b).

\subsubsection{Focal Length}

Figures (6 and 7) show the current-voltage (I-V)-and power-voltage (P-V)- characteristic curves of the PV cell, plotted under the influence of focal lengths for different convex lenses,

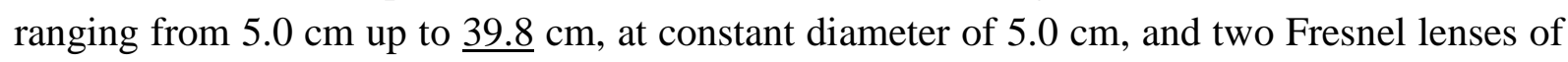
$21.6 \mathrm{~cm}$ and $30.5 \mathrm{~cm}$, at constant diameter of $42.43 \mathrm{~cm}$, respectively. From Fig. (6), it is clearly shown that, using the convex lens, with $5.0 \mathrm{~cm}$ in focal length, the electrical output parameters of the PV cell increased pronouncedly, where an initial values of $\mathrm{I}_{\mathrm{sc}}, \mathrm{V}_{\mathrm{oc}}$ and $\mathrm{P}_{\max }$ of $0.32 \mathrm{~mA}, 0.28$ Volt, $0.04 \mathrm{~mW}$ were shown to increase up to $1.86 \mathrm{~mA}, 0.39$ Volt, and 0.4 $\mathrm{mW}$, respectively. For greater focal lengths $(>5.0 \mathrm{~cm})$ the measured parameters values show slightly increasing, reaching the values of $2.02 \mathrm{~mA}, 0.4$ Volt and $0.47 \mathrm{~mW}$, respectively. Moreover, from Fig. (7), it is reported that, the electrical parameters values $\left(I_{s c}, V_{o c}\right.$ and $\left.P_{\max }\right)$ using Fresnel lens with focal length of $21.6 \mathrm{~cm}$ pronouncedly increased, reaching the values of $78 \mathrm{~mA}, 0.454$ Volt and $21.6 \mathrm{~mW}$, respectively. 
Also, it is shown that, the values of $\mathrm{I}_{\mathrm{sc}}, \mathrm{V}_{\mathrm{oc}}$ and $\mathrm{P}_{\max }$ reached the values of, $69 \mathrm{~mA}, 0.454$ Volt and $18.69 \mathrm{~mW}$, respectively, using higher focal length of $30.5 \mathrm{~cm}$.

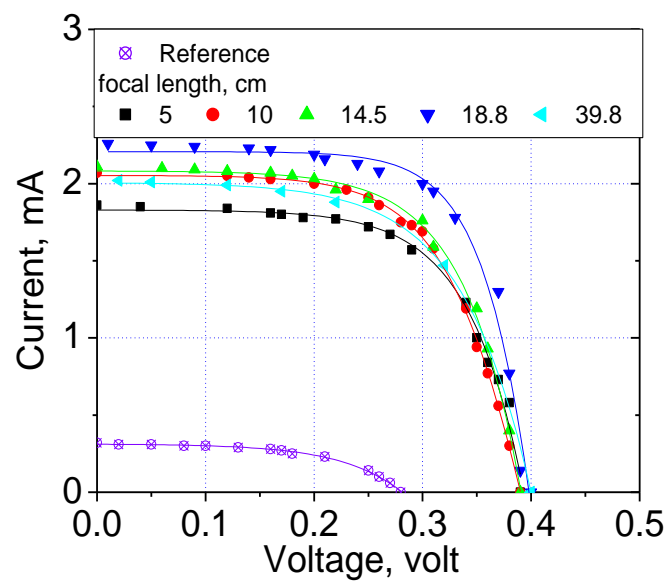

(a)

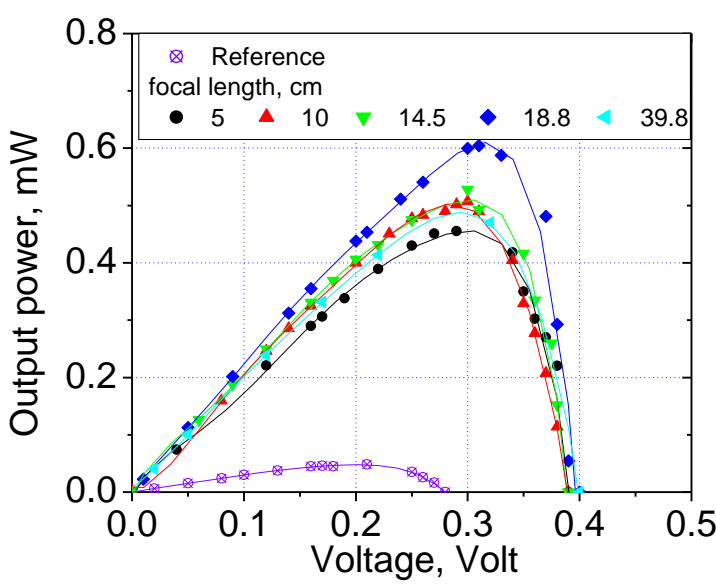

(b)

Fig. (6): (I-V) (a) and (P-V) (b) characteristic curves of PV cell dependency on focal length of different convex lenses at constant diameter.

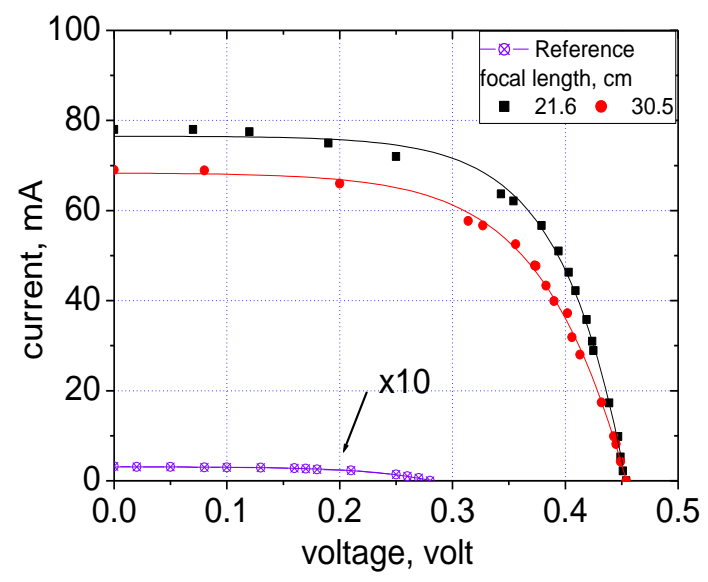

(a)

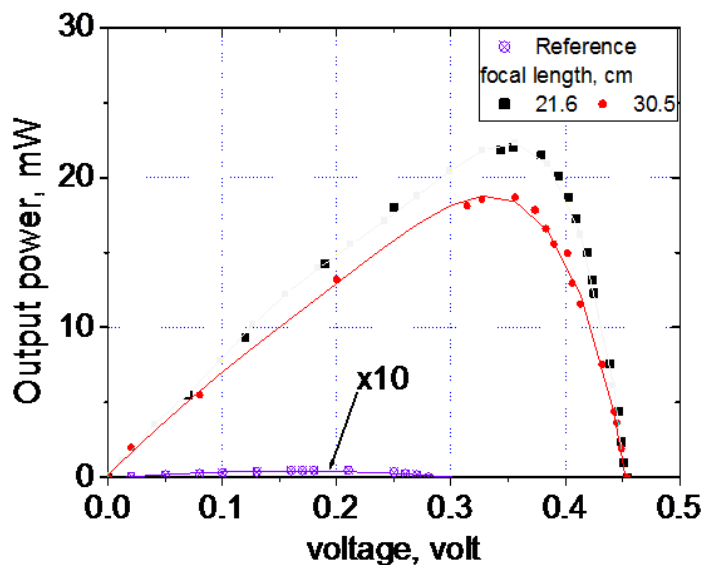

(b)

Fig. (7): Electrical (I-V) (a) - and (P-V) (b) - characteristic curves of PV cell, plotted for two different Fresnel lenses at constant diameter

Finally, Fig. (8) summarizes the obtained results of the focal length effect of convex lens with constant diameter $(5.0 \mathrm{~cm})$ on short circuit current, open circuit voltage, maximum output power, Fill Factor and efficiency of PV cell. 


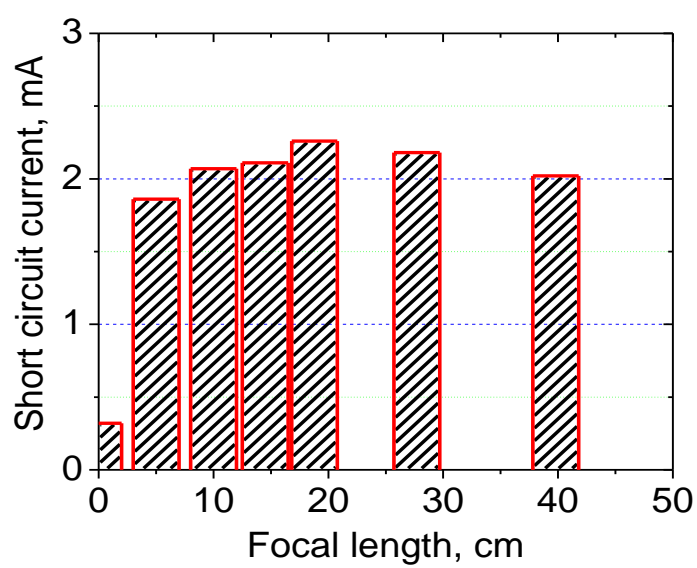

(a)

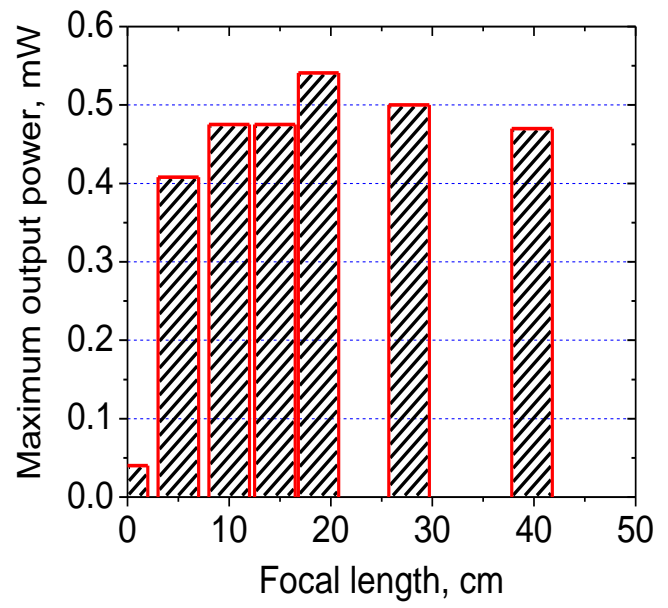

(c)

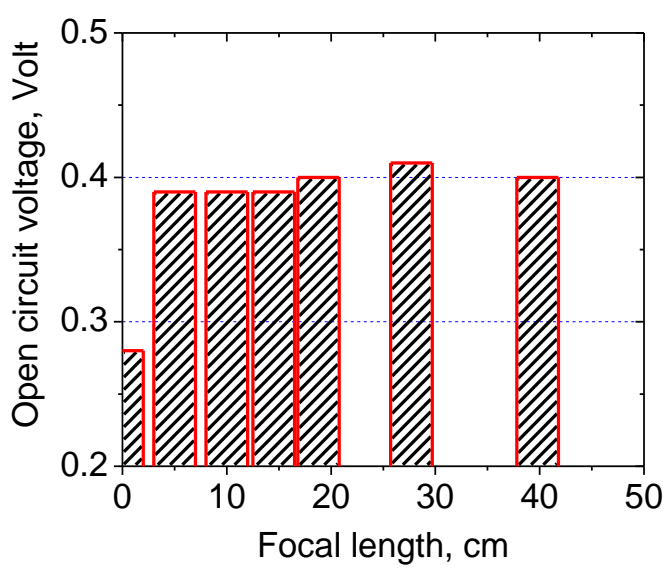

(b)

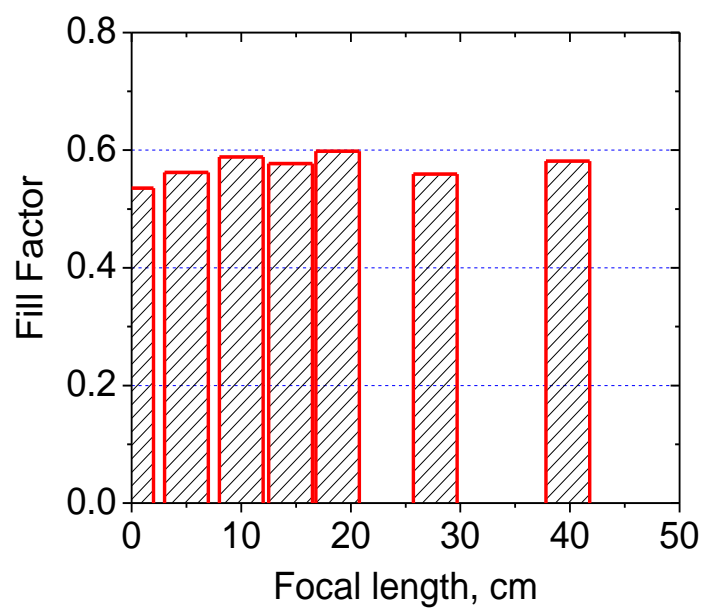

(d)

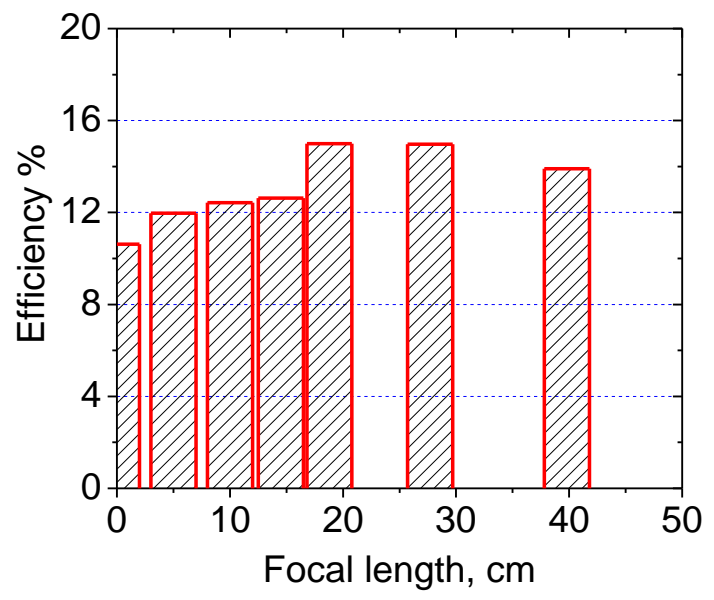

(e)

Fig. (8): Effect of focal length of convex lens $(\mathrm{D}=5.0 \mathrm{~cm})$ on the short circuit current (a), open circuit voltage (b), maximum output power (c), Fill Factor (d) and efficiency (e) of the PV cell 


\subsubsection{Lens Diameter}

In the present part of the work, the effect of lens diameter (convex/Fresnel) on the electrical characteristic curves of the PV cell was investigated. In this concern, seven convex lenses with diameters ranging from $2.0 \mathrm{~cm}$ up to $9.0 \mathrm{~cm}$, at focal length of $39.8 \mathrm{~cm}$, as well seven Fresnel lenses with diameters ranging from $5.0 \mathrm{~cm}$ up to $42.43 \mathrm{~cm}$ at focal length of $21.6 \mathrm{~cm}$ were applied. Figures ( 9 and 10) show the dependency of both the current-voltage (I$\mathrm{V})$-and power-voltage (P-V)-characteristic curves of the PV cell as a function of the lenses diameters, respectively. From which, Figs. (11 and 12) show the effect of convex lens diameter on concentrated light intensity, PV- short circuit current,- open circuit voltage, maximum output power, Fill Factor and - efficiency.

For both lenses, a pronounced linear increase in the concentrated light intensity, PV- $\mathrm{I}_{\mathrm{sc}}$ and $-\mathrm{P}_{\max }$ was reported. On the other hand, $\mathrm{V}_{\mathrm{oc}}$ was proved to be a direct increasing function of concentrated light intensity up to around 10 klux (Fig. 11c, convex lens), but for higher concentrated light intensity, it tends to be saturated (Fig. 12c, Fresnel lens).

Concerning the Fill-factor for PV cell, the obtained results show a slight increase on its value whenever subjected to both lens types, that an average values around 0.5-0.65 were shown. Finally, it is observed that, the efficiency follows a direct increasing function of light intensity up to around 10 klux (Fig. 11f), but for higher light intensity, it tends to be saturated (Fig. 12f). Finally, Table (3) illustrates the summary of the obtained results, and the concentration ratio (C.R.) of the proposed system.

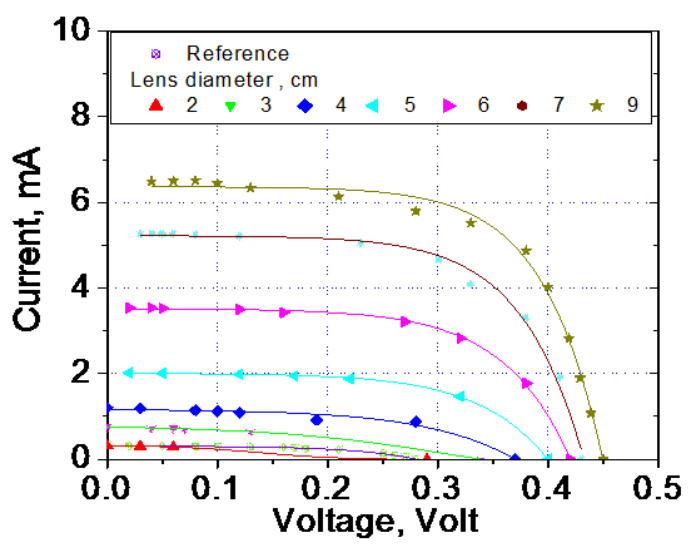

(a)

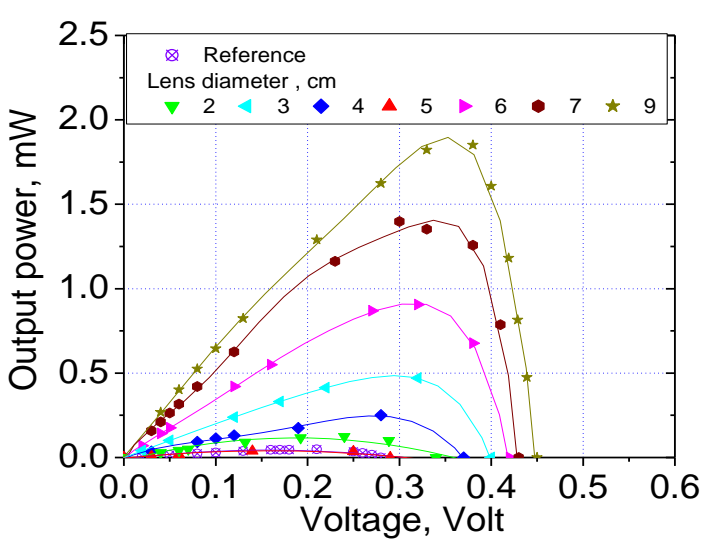

(b)

Fig. (9): Influence of convex lens diameter on (I-V) (a) and (P-V) (b) characteristic curves of the PV cell. 


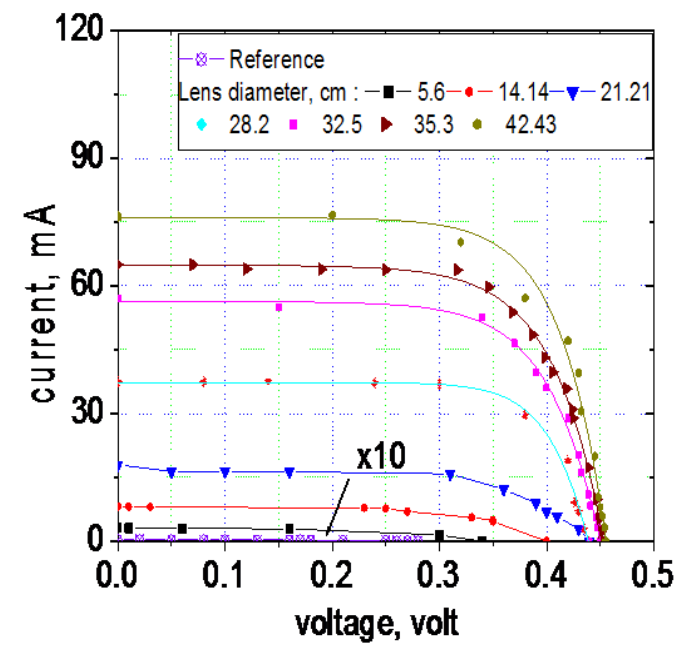

(a)

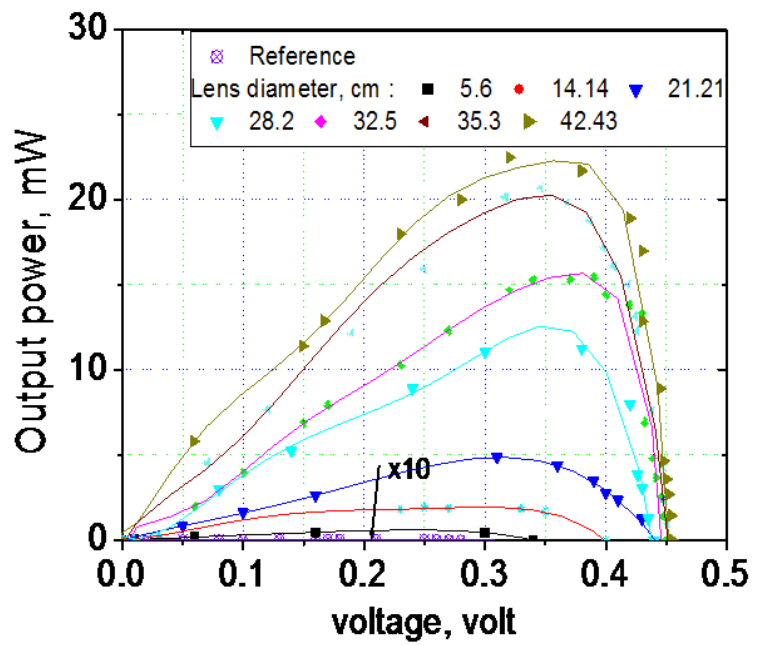

(b)

Fig. (10): Influence of Fresnel lenses diameter on (I-V) (a) and (P-V) (b) characteristic curves of the PV cell.

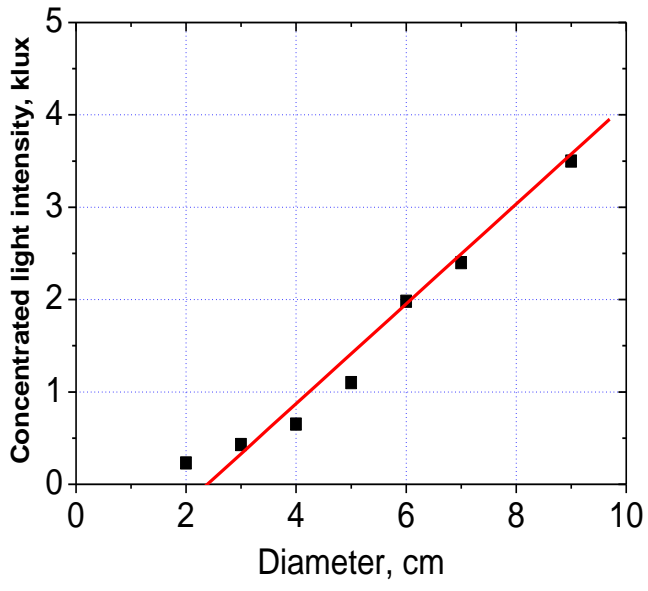

(a)

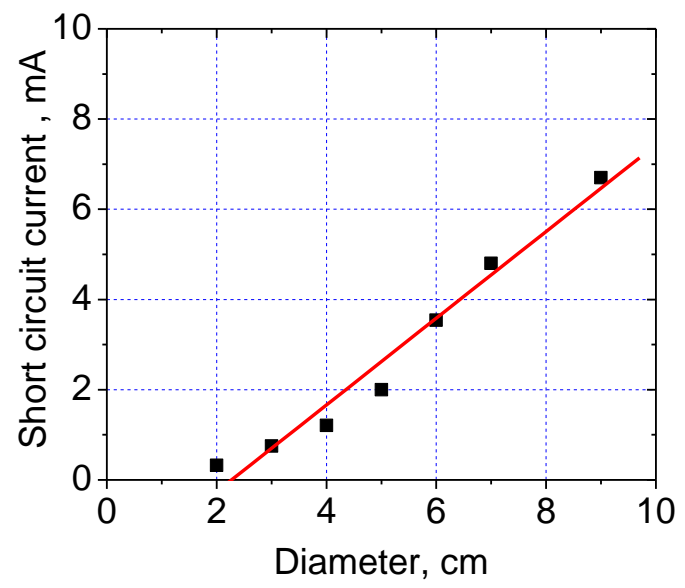

(b) 


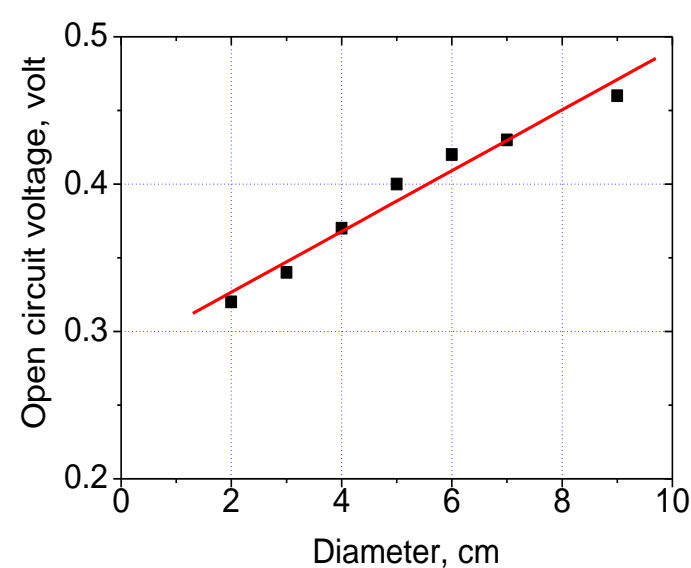

(c)

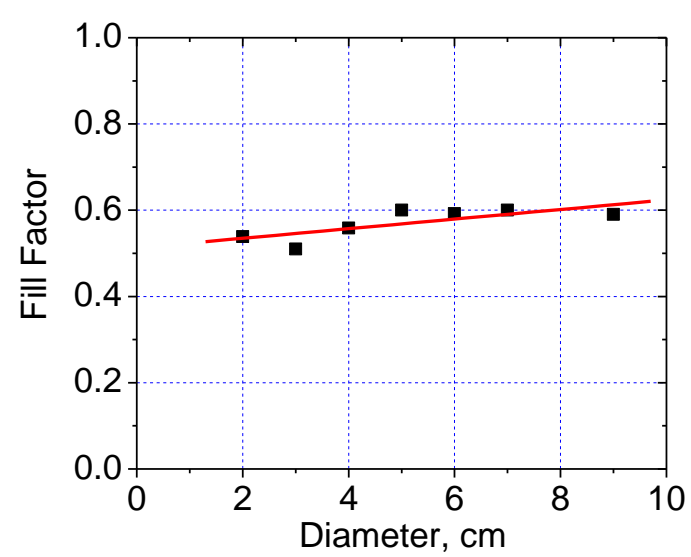

(e)

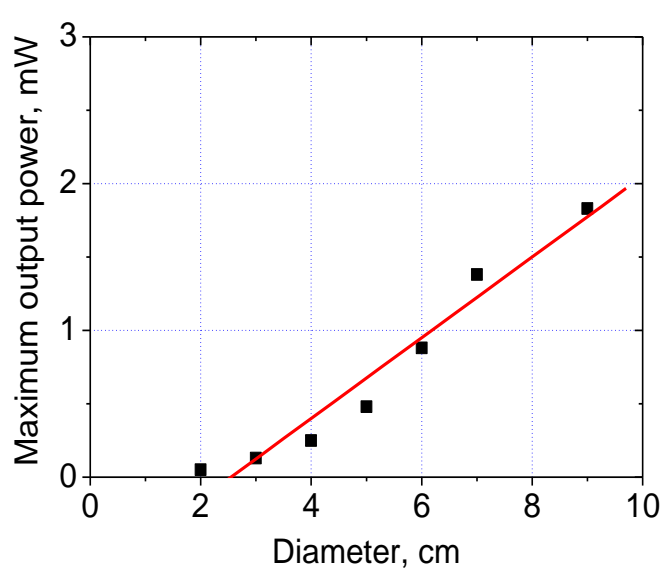

(d)

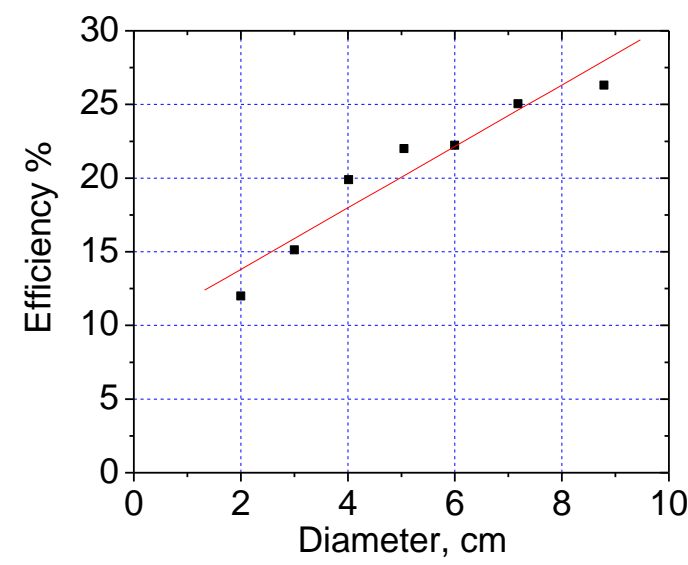

(f)

Fig. (11): Effect of convex lens diameter on concentrated light intensity (a), PV- short circuit current (b), - open circuit voltage (c), - maximum output power (d),

Fill Factor (e) and - efficiency (f).

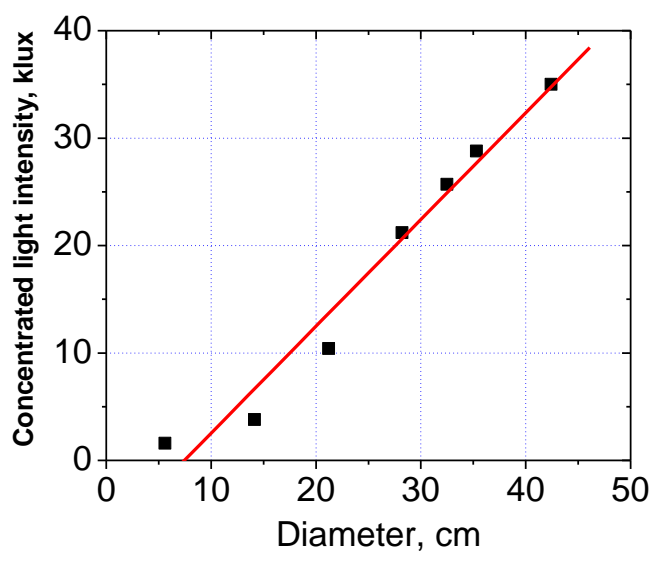

(a)

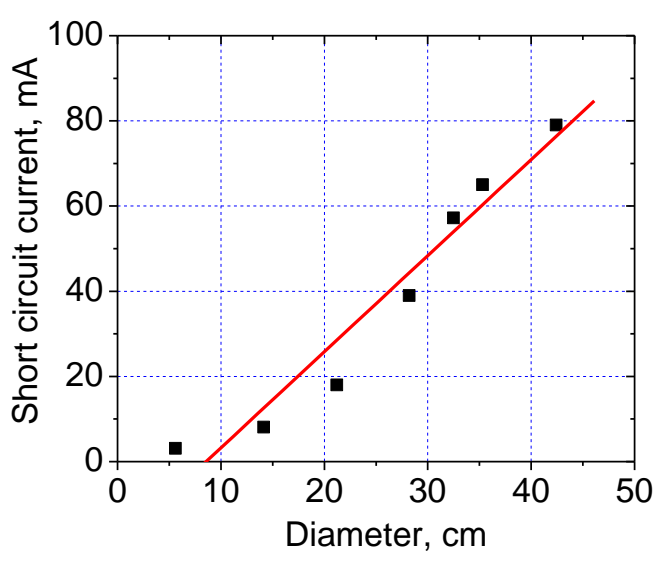

(b) 


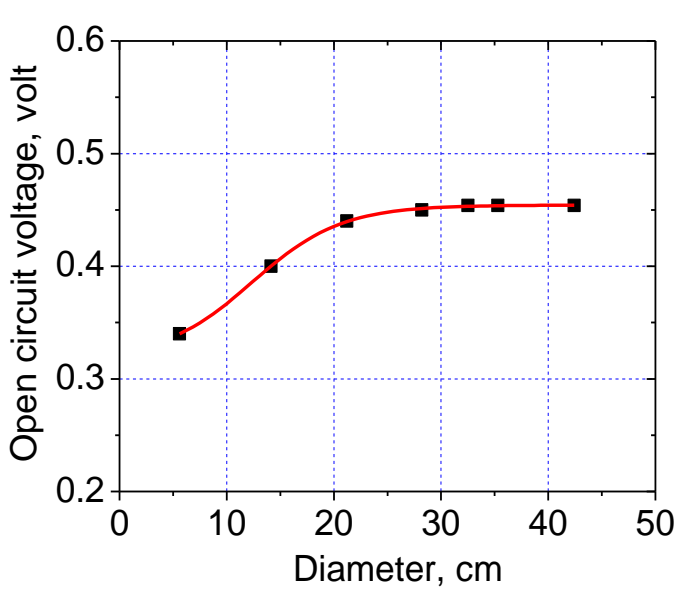

(c)

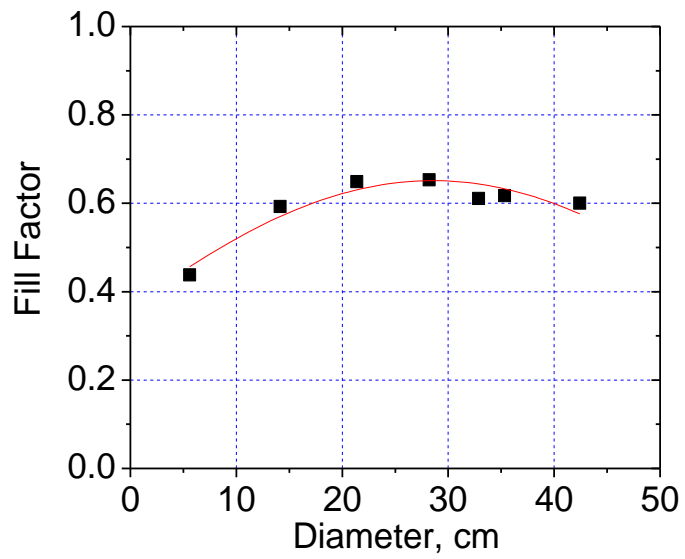

(e)

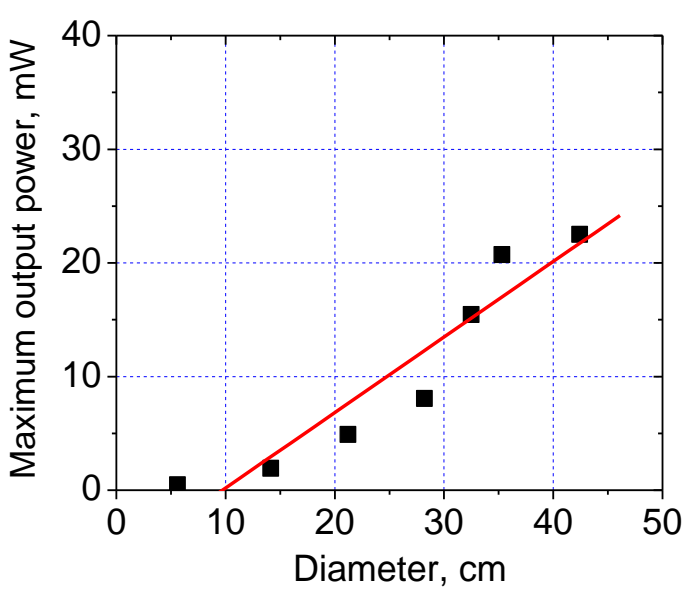

(d)

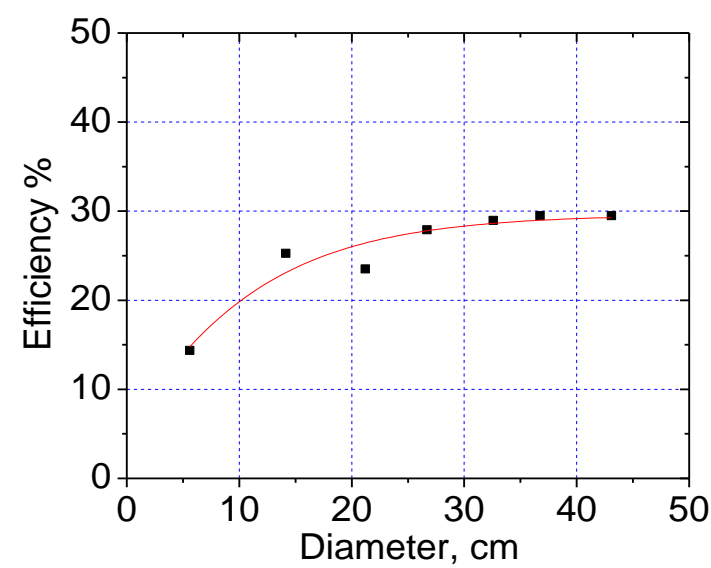

(f)

Fig. (12): Fresnel lens diameter effects on concentrated light intensity (a), PV - short circuit current (b), - open circuit voltage (c), - maximum power (d),

- Fill Factor (e) and - efficiency (f).

Table (3): Summary of the obtained results.

\begin{tabular}{|c|c|c|c|c|c|c|}
\hline \multicolumn{2}{|c|}{ Experiment } & \multirow{2}{*}{$\begin{array}{l}\text { Illum., } \\
\text { klux }\end{array}$} & \multirow[b]{2}{*}{$\mathbf{I}_{\mathrm{sc}}, \mathbf{m A}$} & \multirow[b]{2}{*}{$\eta \%$} & \multirow{2}{*}{$\begin{array}{c}\mathbf{P}_{\max }, \\
\mathbf{m W}\end{array}$} & \multirow{2}{*}{$\begin{array}{c}\text { C.R. for } \\
\mathbf{P}_{\max }\end{array}$} \\
\hline lenses & $\begin{array}{l}\text { Diameter, } \\
\text { cm }\end{array}$ & & & & & \\
\hline Reference & - & $\cdot, 226$ & 0.32 & 9.55 & 0.04 & 1.0 \\
\hline Convex lens & 9.0 & 3.90 & 6.72 & 25 & 1.85 & 46.25 \\
\hline Fresnel lens & 42.43 & $3^{\circ}, \cdot$ & 78 & 30 & 21.6 & 540.0 \\
\hline
\end{tabular}

\section{Conclusions}

From the study, experimental work, results and analysis, it could be concluded that applying concentrated photovoltaic system, based on either convex or Fresnel lenses, was proved to enhance both the concentrated light intensity and photovoltaic system conversion efficiency as well concentration ratio of maximum output power. In this concern, the 
electrical output parameters of silicon photovoltaic cell were shown to increase significantly as a function of lens diameters rather than their focal lengths.

\section{References}

Antonio, et al., "Concentrator Photovoltaics", Vol. 130, pp.1689-1699, Springer Series in Optical Sciences, 2007.

Davis. A, "Fresnel Lens Solar Concentrator Derivations and Simulations", Novel Optical Systems Design and Optimization XIV. Vol. 8129. International Society for Optics and Photonics, 2011.

Guiqiang Li, "Experiment and Simulation Study on the Flux Distribution of Lens-Walled Compound Parabolic Concentrator Compared with Mirror Compound Parabolic Concentrator", Journal of Renewable and Sustainable Energy, Vol. 58, pp. 398-403, 2013.

ISO, "Photography-Apertures and Related Properties Pertaining to Photographic LensesDesignations and Measurements", ISO 517, 2008.

$$
\text { https://www.iso.org/obp/ui/\#iso:std:iso:517:ed-3:v1:en }
$$

K. Shanks, et al., "Optics for Concentrating Photovoltaics: Trends, Limits and Opportunities for Materials and Design”, Renewable and Sustainable Energy Reviews, Vol.60, pp. 394-407, 2016.

M. Wiesenfarth, et al., "Investigation of Different Fresnel Lens Designs and Methods to Determine the Optical Efficiency", 10 ${ }^{\text {th }}$ International Conference on Concentrator Photovoltaic Systems AIP Conf. Proc. 1616, pp. 97-101, 2014.

N. Tien and S. Shin, "A Novel Concentrator Photovoltaic (CPV) System with the Improvement of Irradiance Uniformity and the Capturing of Diffuse Solar Radiation”, Appl. Sci., Vol. 6, pp.251, 2016.

P. K. Trivedi, et al., "Performance Evaluation of a Prototype Solar Collector Using Convex Lenses for Varying Mass Flow Rate of the Heat Transfer Fluid”, SSRG International Journal of Mechanical Engineering, Vol.2, pp. 40-42, 2015.

R. Leutz and A. Suzuki, "Nonimaging Fresnel Lenses: Design and Performance of Solar Concentrators", Springer Series in Optical Sciences, Vol. 83, 2001.

S. Avireni, "Converging Lens Solar Concentrator and Their Position Control Using A Microprocessor for Increasing the Efficiency of Solar Photovoltaic Energy Conversion", ${ }^{3} \mathrm{rd}$ International Conference: Sciences of Electronic, Technologies of Information and Telecommunications (IEEE), pp. 3-8, March 27-31, TUNISIA, 2005. 
Stadtländer CT, "Scanning Electron Microscopy and Transmission Electron Microscopy Of Mollicutes: Challenges And Opportunities”, Modern research and educational topics in microscopy 1, pp 122-131, (2007).

Y. A. Abdel-hadi, "Development of Optical Concentrator Systems for Directly Solar Pumped Laser Systems”, PhD., Technical University of Berlin Institute of Optics, 2005. 
الملخص العربى

\section{جدوي الأنظمة الكهروضوئية المركزة اعتمادا على العدسات المحدبة وفرينيل}

أسماء سلامة عبدالتواب إبراهيم (') صفاء محمد رشدى الغنام (') ـوفاء عبدالباسط عبدالرحمن (') فؤاد عبد المنعم سعد سليمان(")

1. معل أبحاث الإكترونياتـ قسم الفيزياءـ كلية البنات للأداب والعلوم والتربيةـ جامعة عين شمس- القاهرةجمهورية مصر العربية

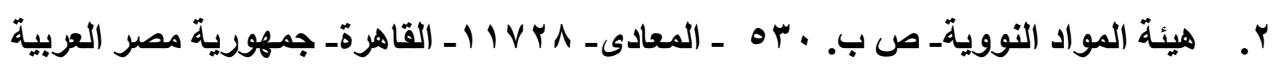

تناول البحث المعروض در اسة عملية تطبيقية لتحسين أداء الأنظمة الكهروضوئية المركزة إعتمادا على كلا من العدسات المحدبة و عدسات فرينيل ذات الخصائص الهندسية المختلفه (أقطار و ابعاد بؤرية)، تحت تأثير مصدر ضوئي صناعي "المصباح المتوهج" محاكاة لضوء الثمس. ثم إجراء العديد من التهات التجارب العملية لدراسة تأثثر الأقطار والأبعاد البؤرية للعدسات علي كافة المعاملات الكهربائية للخلية

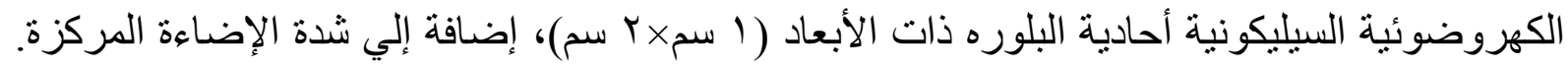

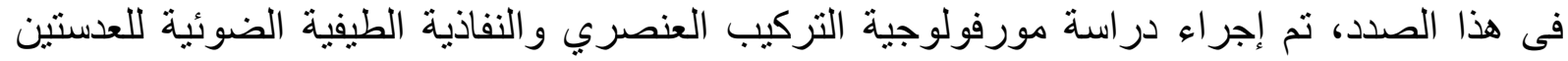
اعتمادا على تقنيتى المجهر الإلكتروني الماسح (SEM) ومطياف الاشعه تحت الحمراء (FT-IR)؛

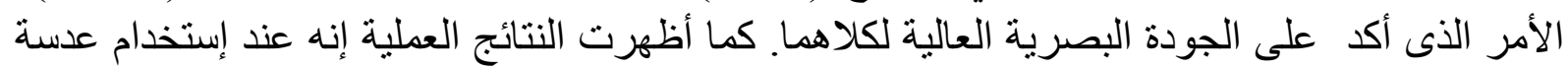

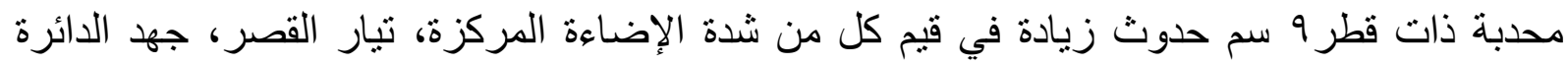

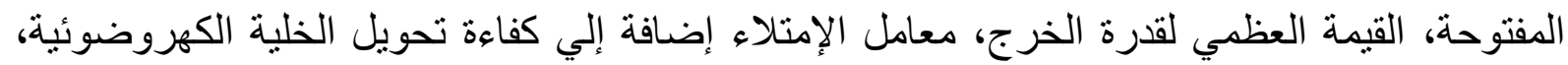

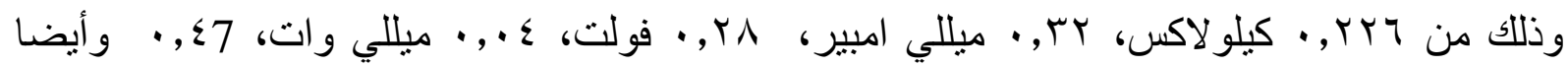

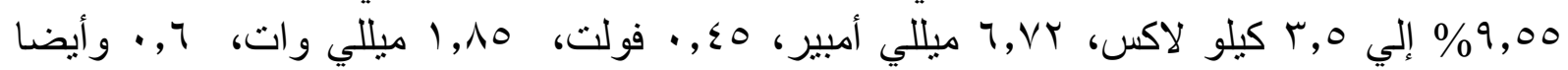

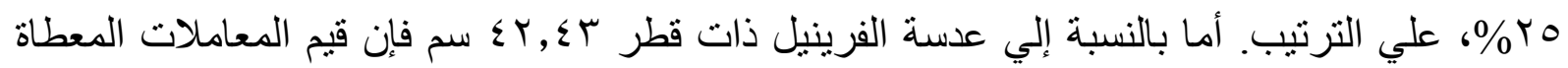

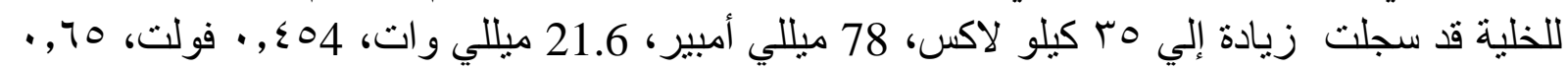
و أيضا · ب\%٪، علي الترتيب. 